\title{
An audit of care received by patients injured during sporting activities
}

\author{
S. GRIMBLE, I. G. KENDALL \& M. J. ALLEN \\ Department of Accident and Emergency Medicine, Leicester Royal Infirmary, Leicester
}

\section{SUMMARY}

A summary of injuries sustained by 340 sportsmen over 9 successive weekends from 16 November 1991 to 12 January 1992 attending an accident and emergency (A\&E) department is presented. Most injuries occurred in young males usually as a result of soccer or rugby. Sixty-seven per cent of patients were discharged with no further followed up in hospital. Seventy-two per cent of patients were X-rayed, $33 \%$ of X-rays showed a fracture or dislocation. A total of 193 attendees received minimal treatment, (defined as discharge with advice only, simple analgesia or strapping only with no hospital follow-up) and of these 152 were X-rayed. A total of 100 patients who received minimal treatment were selected randomly by computer to receive a follow-up letter asking about certain issues relating to their care in the A\&E department. Most patients felt that the A\&E Department was the most appropriate source of treatment for their sports injury, and over half attended specifically for an X-ray examination. Despite the doctors view that many of these minor injuries could have been self-treated, few patients felt able to treat future similar minor injuries themselves. They were, however, more likely to go elsewhere for treatment on subsequent occasions.

\section{INTRODUCTION}

A\&E departments deal with a large number of recreational sportsmen who injure themselves at weekends and present when departments are busy and have reduced numbers of staff. Our impression, also shared by others (Hutson, 1987; Thomas, 1988), is that many of these injuries are perceived by A\&E staff as being selfinflicted, apparently minor, and needing little intervention from the A\&E department. Sporting injuries are common, one in ten sportsmen being injured every year and three out of four of those with manual jobs losing, on average, 10 days

Correspondence: S. Grimble, School of Medicine, University of Leicester, Leicester LE1 $7 R H$. 
from work (Stableforth, 1987). The management of acute sporting injuries has historically been less than ideal (Sperryn \& Williams, 1975), with up to a third of attendances at a sports clinic being due to acute injuries that, without satisfactory? rehabilitation, had become chronic. What appears to be trivial to the doctor is not always perceived as such by the sportsman. Although minor injuries may not prevent the keen sportsman from working, some may suffer psychologically as: well as physically if their leisure activity, which has become so important to their overall sense of well-being, has to be curtailed.

In this study we attempted to document the amount of work generated by weekend sporting activities in a large $A \& E$ department. In those discharged with $\vec{P}$ minimal treatment an assessment was made of the patients' perception of the severity of their condition, whether they felt that they had received sympathetie treatment from the staff and if they had received advice on recovery from theie. injury.

\section{METHODS}

All patients presenting to the A\&E Department from 9 a.m. on Saturday to mid $\frac{\mathbb{0}}{\mathbb{N}}$ night on Sunday over nine successive weekends were entered into the study $\frac{\vec{b}}{\sigma}$ Details of the patients' sport, time lapse to presentation, injuries, investigationt $\frac{\mathscr{\Phi}}{\mathrm{T}}$ treatment and disposal were entered onto a computer database and later analyseg Those patients who received only basic treatments (strapping, advice or analgesifis) and no follow up were identified and 100 were randomly selected to receive $=0$ postal questionnaire which could be returned anonymously enquiring about:

(1) the availability of medical advice at site;

(2) reason for attendance at hospital;
(3) whether or not they would re-attend with similar injury in light of their experience;

(4) degree of satisfaction with treatment;

(5) whether they felt staff were sympathetic towards their injury; and

(6) level of information given on recovery.

\section{RESULTS}

A total of 4680 patients attended over the study period, 340 were due to injuries sustained in sport. Most were young males (Table 1). At this time of the yearo soccer and rugby accounted for most of the injuries (Table 2). Of patients, 92\% presented within $24 \mathrm{~h}$ of the injury. Consultation was most frequently for headw and facial injuries, half of which were lacerations requiring suturing (Table 3). Sof $\bar{F}$ tissue injuries accounted for $57 \%$ of injuries, $79 \%$ of which were X-rayed (Table 4). Common treatments given are shown in Table 5. Only one patient was referred? directly to the physiotherapy department but this reflects the availability of a0 
Table 1. Age distribution of attendees

\begin{tabular}{lc}
\hline Age group (years) & Number \\
\hline$<10$ & 6 \\
$10-20$ & 122 \\
$21-30$ & 146 \\
$31-40$ & 54 \\
$>40$ & 12 \\
Total & $340^{*}$ \\
\hline
\end{tabular}

* Male, 316; female, 24.

Table 2. Sport being played when injury was received

\begin{tabular}{lr}
\hline Game & Number \\
\hline Soccer & 142 \\
Rugby & 87 \\
Hockey & 11 \\
Squash & 6 \\
Basketball & 5 \\
Horse Riding & 4 \\
Netball & 4 \\
Judo & 4 \\
Skiing & 3 \\
Others & 19 \\
Not recorded & 55 \\
\hline
\end{tabular}

Table 3. Location of injuries

\begin{tabular}{|c|c|c|c|c|}
\hline Location of injury & Total & Fractures & & Lacerations \\
\hline Head and face & 83 & 15 & & 44 \\
\hline Thigh knee lower leg & 81 & 12 & & 0 \\
\hline Foot/ankle & 71 & 13 & & 10 \\
\hline Hand/wrist & 48 & 17 & & 2 \\
\hline Neck/shoulder & 32 & 4 & & 0 \\
\hline Arm/elbow & 9 & 3 & & 0 \\
\hline Back & 6 & 0 & & 0 \\
\hline Other & 10 & 2 & (rib) & 0 \\
\hline
\end{tabular}

physiotherapist at the weekend and departmental policy. Patients attending for follow-up clinics mostly did so 1-2 weeks after the injury occurred and some were then referred for physiotherapy. Sixty-seven per cent were discharged from further hospital follow-up, although some of these would have returned to their general practitioners for suture removal (Table 6). 
Table 4. Types of injury

\begin{tabular}{lcc}
\hline Type of injury & Number & X-ray ordered \\
\hline Fracture & 66 & 66 \\
Laceration & 56 & 10 \\
Dislocation/subluxation & 14 & 14 \\
Brief loss of consciousness only & 8 & 2 \\
Soft tissue injury & 194 & 153 \\
Pneumothorax & 1 & 1 \\
Corneal abrasion & 1 & 0 \\
Total & 340 & 246 \\
\hline
\end{tabular}

Table 5. Types of treatment received

\begin{tabular}{lc}
\hline Treatment & Number \\
\hline Strapping only & 92 \\
No treatment & 60 \\
Suturing & 54 \\
Strapping + follow up & 47 \\
Analgesia only & 41 \\
Plaster of paris & 23 \\
Others & 23 \\
\hline
\end{tabular}

Table 6. Discharge or suggested followup procedure

\begin{tabular}{lr}
\hline Disposal & Number \\
\hline Discharged & 228 \\
A\&E review & 48 \\
Orthopaedic & 47 \\
Maxillofacial & 8 \\
ENT & 7 \\
Surgeons & 1 \\
Plastics & 1 \\
Total & 340 \\
\hline
\end{tabular}

\section{Questionnaire}

Sixty-seven replies were received from the 100 questionnaires sent to those with apparently minor injuries. In half the cases (33) there was said to be no first aider, physiotherapist or doctor at the scene of the accident. Of these patients, $38 \%$ considered that they needed urgent treatment, $43 \%$ felt that their GP would not be available and half of these considered GP care to be inappropriate for their injury. When asked their main reason for attendance, $51 \%$ stated that it was for anc X-ray examination, only $34 \%$ gave seeing a doctor as the first purpose of their? visit. Of respondents, $76 \%$ recalled having received some advice on the length of $\frac{0}{0}$ 
their likely recovery. When asked whether they would attend the department again with a similar injury only $30 \%$ felt that they would but the majority would still seek some sort of medical advice elsewhere (see Table 7), $18 \%$ felt that staff were unsympathetic to their injury and the degree of satisfaction with the overall care was less in this group (Table 8).

\section{DISCUSSION}

Those presenting with injuries sustained playing sport in this survey accounted for approximately $7 \%$ of attenders at the weekend in our department, and for $6 \%$ of new attendances at A\&E follow-up clinics. This does not take into account patients who attended on weekdays following sports injuries sustained at the weekend. These figures are consistent with those published elsewhere (Stapleforth 1987). Of the sporting injuries seen, most were of an acute nature and would not have differed in many ways from injuries sustained from other causes. Although soft tissue injuries numerically accounted for the largest number of injuries seen it is of note that wounds, which require a disproportionate input of medical and nursing time to treat, were also very common. Guidelines within the department have reduced the number of plasters used in soft tissue injuries and this audit confirms their use in ankle sprains to be low. Despite this, and an interest within the department in sports injuries, there is a low referral rate for early physiotherapy, a service which is considered by some to be of importance in reducing chronic disability (Sperryn \& Williams 1975). An audit of physiotherapy use is currently taking place.

Table 7. Likely place of first attendance if similar injury occurred

\begin{tabular}{lc}
\hline Place of attendance & Number \\
\hline A\&E & 20 \\
GP & 29 \\
Physiotherapist & 10 \\
Self-treatment & 8 \\
\hline
\end{tabular}

Table 8. Degree of satisfaction with treatment

\begin{tabular}{|c|c|c|c|c|c|c|}
\hline \multirow[t]{2}{*}{$\begin{array}{l}\text { View of } \\
\text { overall } \\
\text { treatment }\end{array}$} & \multicolumn{2}{|c|}{ Total } & \multicolumn{2}{|c|}{$\begin{array}{c}\text { Receiving } \\
\text { unsympathetic } \\
\text { treatment }\end{array}$} & \multicolumn{2}{|c|}{$\begin{array}{l}\text { Receiving } \\
\text { sympathetic } \\
\text { treatment }\end{array}$} \\
\hline & No. & $(\%)$ & No. & (\%) & No. & $(\%)$ \\
\hline Excellent & 10 & 15 & 1 & 8 & 9 & 16 \\
\hline Good & 32 & 48 & 3 & 25 & 29 & 53 \\
\hline Satisfactory & 19 & 28 & 5 & 42 & 14 & 25 \\
\hline Poor & 5 & 8 & 2 & 16 & 3 & 5 \\
\hline Appalling & 1 & 1 & 1 & 8 & 0 & 0 \\
\hline
\end{tabular}


Few of those injured were likely to be first class athletes. Most are partaking in $\frac{\bar{D}}{0}$ sport to achieve fitness (Stableforth, 1990), and are most at risk of injury from $\underset{\mathbb{\infty}}{3}$ aggressive play in contact sport.

It is very likely that the injuries sustained in this group of patients led to $a_{\bar{G}}^{\vec{m}}$ considerable amount of lost time from work. Many of those with fractures would 7 have been unable to work with plaster casts and two-thirds of the total group were asked to re-attend the hospital for clinics occurring in normal office hours.

Patients who have the least severe injuries are likely to wait longer for examination $\mathbb{\varnothing}$ and often receive little treatment apart from advice which may be given hurriedlyos in a busy department. Most considered the A\&E department to be an appropriate $\vec{\circ}$ place for the management of their injury particularly as an X-ray was considered $\vec{\omega}$ by the patient to be of paramount importance in the diagnosis of their condition. This view is supported to some extent by the doctors ordering a large number of 3 . radiological investigations. Of those with minor injuries, $18 \%$ felt that they had obtained unsympathetic treatment from staff, and this group of patients were less $\dot{\omega}$ likely to be satisfied with their overall care. This article does not attempt to answer $\tilde{C}_{\tilde{D}}$ whether the medical care received for these injuries was appropriate but clearlyo patients perceive staff attitudes to be important. This is confirmed in published work on patients' complaints (Richmond \& Evans, 1989; Reichl \& Sleet, 1990). Weळ do not know whether this particular group of patients received any less sympathetic $\frac{\vec{\Phi}}{\mathrm{P}}$ treatment than others but further studies of quality assurance in other patient $\frac{0}{\sigma}$ groups should be performed together with staff education on communication skills.

\section{REFERENCES}

Bedford P. \& MacCauley D. C. (1984) Attendance at a casualty department for sports related injuries. British Journal of Sports Medicine 18, 116-120.

Hutson M. (1987) Why sports injury clinics? British Medical Journal 296, 1210.

Reichl M. \& Sleet R. A. (1990) Complaints against accident and emergency department: current trends Archives of Emergency Medicine 7, 246-248.

Richmond P. W. \& Evans R. C. (1989) Complaints and litigation- three year experience at a busy accident and emergency department 1983-1985. Health Trends 21, 42-45.

Sperryn P. N. \& Williams J. G. P. (1975) Why sports injury clinics? British Medical Journal 3, 364-365. Stableforth P. G. (1990) Sports Injuries. Injury 21, 311-313.

Stableforth P. G. (1987) Why sports injury clinics? British Medical Journal 296, 799.

Thomas P. (1988) Sports medicine. Practitioner 232, 830-831. 